\title{
The Association between Smartphone Addiction and Insomnia Incidence in Students of the Faculty of Medicine Udayana University Batch of 2020 during the Coronavirus Disease-19 Pandemic
}

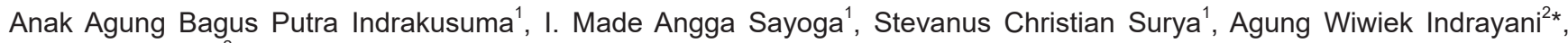 \\ I. Gusti Ayu Artini ${ }^{2}$ \\ ${ }^{1}$ Medical Education Study Program, Faculty of Medicine, Udayana University, Bali, Indonesia; ${ }^{2}$ Department of Pharmacology \\ and Therapy, Faculty of Medicine, Udayana University, Bali, Indonesia
}

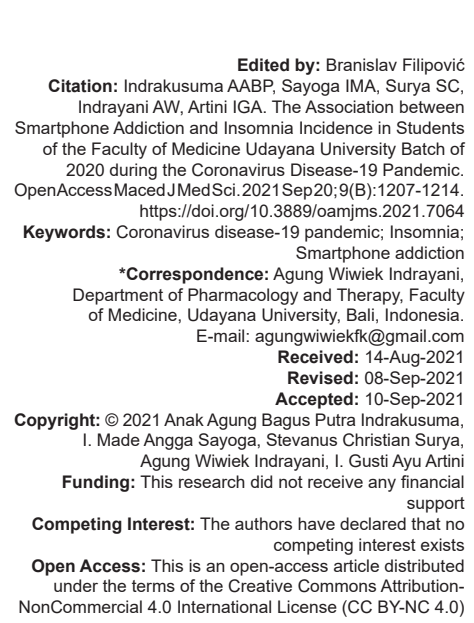

\begin{abstract}
BACKGROUND: The use of smartphones is increasing in the coronavirus disease (COVID-19) pandemic for various purposes, this encourages smartphone addiction. In addition, the incidence of insomnia has also increased in the pandemic era.

AIM: This study was conducted to find an association between smartphone addiction and the incidence of insomnia, especially among students of the Faculty of Medicine, Udayana University.

METHOD: This research is a descriptive-analytic study with the cross-sectional method, using two main questionnaires, Smartphone Addiction Scale-Short Version, and Insomnia Severity Index. Questionnaires were distributed using Google forms and then collected and analyzed using software SPSS version 25.

RESULT: Overall the total research respondents with the inclusion criteria in this study amounted to 364 people. The results showed that 212 respondents $(58.24 \%$ ) had a high level of smartphone addiction and 152 respondents $(41.76 \%)$ had a low level of smartphone addiction. In addition, 187 respondents (51.37\%) experienced mild insomnia, 87 respondents $(23.9 \%)$ experienced moderate insomnia, 13 respondents $(3.57 \%)$ experienced severe insomnia, and 77 respondents $(21.15 \%)$ did not experience insomnia. Based on the results of data analysis, it was found that smartphone addiction had a significant relationship $(p=0.002)$ with weak and positive correlation $(r=0.162)$ to the
\end{abstract} incidence of insomnia.

CONCLUSION: It was found that the majority of respondents experienced high levels of smartphone addiction and mild insomnia. Another finding suggests the higher addiction to the smartphones, the more severe insomnia suffered.

\section{Background}

The World Health Organization (WHO) on March 11, 2020, has declared an outbreak of a novel coronavirus (Coronavirus Disease [COVID-19]) as a global pandemic [1]. The global pandemic causes various impacts, especially in Indonesia. Thus, the government plays an important role in policymaking to inhibit the process of spreading COVID-19. One of the policies implemented by the government of Indonesia is Large-Scale Social Restrictions. This policy is considered ineffective because it affects many sectors of life such as the economy, finance, and education [2]. The impact of the COVID-19 pandemic in the education sector, for example, the closing of various schools and educational institutions and starting to conduct distance learning in their respective homes [3].

Due to the reduction in social contact, the implementation of distance learning requires deeper interaction and communication from students and lecturers than conventional learning [4]. Communication in the implementation of learning between students and lecturers/teachers is done by utilizing the current technological developments are online or virtual. Some of the platforms used in general are social media such as Facebook, WhatsApp, and Skype and/or through web conferencing applications such as Zoom, Webex, or Google Meet. In using the application, of course, students, and lecturers/teachers need to prepare hardware in the form of computers/PCs, laptops, or smartphones [3], [4].

The financial inequality of students causes not all of them to be able to use computers or laptops, thus media that are widely chosen are smartphones [5]. In the pandemic era, smartphones can be used as effective learning media, important information centers, student communication media, as well as tools to increase student insight [5]. Various advantages can be obtained from the use of smartphones in distance learning. However, excessive use of smartphones also results in many losses, where students become addicted to the features provided in smartphones. If users are addicted, then users will feel anxious if they do not use a smartphone for too long [6]. 
This condition is called smartphone addiction, which is often associated with negative impacts on humans [7]. In a study conducted by Boumosleh and Jaalouk, of 688 students, $49 \%$ of them used smartphones excessively to become smartphone-addicted [8]. The incidence of smartphone addiction has increased among children and students during the COVID-19 pandemic. This is due to reduced physical activity, thus increasing the time of using the smartphone [6].

The increase in the incidence of smartphone addiction also increases the negative impacts arising from smartphone addiction, such as symptoms of depression, anxiety disorders, and decreased sleep quality [9], [10]. Decreased sleep quality can cause insomnia, which is a difficulty in maintaining the quality and quantity of sleep. It is characterized by difficulty initiating sleep, difficulty maintaining sleep, and waking up quickly [11]. The incidence of insomnia during the global pandemic has also increased, one of the pieces of evidence of which is a study conducted in Greek society. In this study, $37.6 \%$ of the sample scored above the score limit for insomnia. This percentage is greater than the worldwide prevalence of insomnia, estimated before the pandemic between $3.9 \%$ and $22 \%$ exhibiting sleep disturbances [12]. In addition, another study conducted on the French population was also found to be higher than the prevalence of insomnia worldwide [13].

Based on the review of the above studies, deeper insights and knowledge are needed regarding the increase in smartphone addiction and the incidence of insomnia during the pandemic. Therefore, in this study, the authors raised variables regarding smartphone addiction and the incidence of insomnia. Several studies regarding the association between the incidences of insomnia caused by the effects of smartphone addiction have been carried out. A study was conducted in India with a sample population of medical students. The study reviewed the prevalence of smartphone addiction and its effect on sleep quality. The study did not take place during a pandemic, and there were no studies on insomnia [14]. Several other studies have also raised the relationship between smartphone addiction and the incidence of insomnia, but they do not specifically discuss insomnia and do not exist in Indonesia [14], [15], [16], [17]. However, this research can be used as a support for the literature and a benchmark for the results of the research that will be conducted this time.

In this study, samples were taken from students of the Faculty of Medicine, Udayana University Batch 2020 during a pandemic. The number of batches of the Faculty of Medicine, Udayana University is 657 people. With such a number, it supports the implementation of this research. In this study, there are several urgencies compared to other studies. This research can be used to support the availability of data from new regions in Indonesia, especially the Faculty of Medicine, Udayana University.
The research results obtained can later be used as the basis for further research. In terms of time, the research is relatively new, because it was carried out in the middle of a pandemic. This research is important to assess the online education system that exists in Indonesia in dealing with the pandemic, whether they affect sleep disturbances or not. This research was conducted after considering various aspects such as the need for funds that can be met, as well as the pandemic situation that makes it difficult for social contact. Thus, this research is realistic to carry out. Based on this background, the authors are interested in knowing the association between smartphone addiction and the incidence of insomnia in students of the Faculty of Medicine, Udayana University batch 2020 during the COVID-19 pandemic.

\section{Method}

This research was conducted online at the Faculty of Medicine Udayana University and is a descriptive-analytic study with a cross-sectional method. The number of samples in this study based on the Solvin formula is a minimum of 249 respondents. The independent variable in this study was smartphone addiction among students of the Faculty of Medicine Udayana University batch 2020 during the COVID-19 pandemic. The dependent variable in this study was the incidence of insomnia in students of the Faculty of Medicine, Udayana University batch 2020 during the COVID-19 pandemic. Data were collected using a quantitative questionnaire method. The data used in this study are primary and secondary data. Primary data were obtained from the results of questionnaires distributed to respondents through a Google form. Secondary data were obtained from the literature to corroborate the research results through literature review from various search engines such as PubMed, Science Direct, and Google Scholar. The research data were processed and analyzed using the Statistical Package for the Social Science (SPSS) version 25 program with a 95\% confidence interval $(\alpha=0.05)$. Data analysis includes two parts, namely, univariate and bivariate analysis. The univariate analysis aims to describe the characteristics of each variable to be studied, namely, smartphone addiction and the incidence of insomnia by making a frequency distribution table. Bivariate analysis was conducted to determine the relationship between variables. The test used to see the relationship between smartphone addiction and the incidence of insomnia is a correlation test (Spearman). The results were considered significant if $p<0.05$. This research has been declared ethically feasible by the research ethics commission of the Faculty of Medicine Udayana University/Sanglah Central General Hospital Denpasar number: 1317/ UN14.2.2.VII.14/LT/2021 dated May 7, 2021. 


\section{Results}

Overall the total research subjects with the inclusion criteria in this study amounted to 364 respondents. The characteristics of the respondents are shown in Table 1. The age range of the respondents in this study is 17-21 years with the majority of respondents being in the 19-year age group ( $n=209 ; 57.42 \%$ ). In terms of gender characteristics of research subjects, the number of female respondents ( $n=289 ; 79.40 \%$ ) was higher than the number of male respondents $(n=75$; $20.60 \%$ ). All respondents came from six different health science study programs, include medical education ( $n=96 ; 26.37 \%)$, nursing $(n=78,21.43 \%)$, public health ( $\mathrm{n}=72 ; 19.78 \%)$, physiotherapy $(\mathrm{n}=51 ; 14.01 \%)$, dentist education ( $n=43 ; 11.81 \%$ ), and psychology ( $n=24 ; 6.59 \%)$.

Table 1: Characteristics of respondents

\begin{tabular}{|c|c|c|}
\hline Variable & Frequency (n) & Percentage \\
\hline \multicolumn{3}{|l|}{ Age } \\
\hline 17 years & 5 & 1.37 \\
\hline 18 years & 117 & 32.14 \\
\hline 19 years & 209 & 57.42 \\
\hline 20 years & 32 & 8.79 \\
\hline 21 years & 1 & 0.27 \\
\hline \multicolumn{3}{|l|}{ Gender } \\
\hline Female & 289 & 79.40 \\
\hline Male & 75 & 20.60 \\
\hline \multicolumn{3}{|l|}{ Study programs } \\
\hline Medical education & 96 & 26.37 \\
\hline Public health & 72 & 19.78 \\
\hline Nursing & 78 & 21.43 \\
\hline Physiotherapy & 51 & 14.01 \\
\hline Psychology & 24 & 6.59 \\
\hline Dentistry education & 43 & 11.81 \\
\hline \multicolumn{3}{|l|}{ The average duration of smartphone uses per day } \\
\hline$<4 \mathrm{~h}$ & 20 & 5.49 \\
\hline $4-8 \mathrm{~h}$ & 207 & 56.87 \\
\hline$>8 \mathrm{~h}$ & 137 & 37.64 \\
\hline \multicolumn{3}{|l|}{ Most types of smartphones use } \\
\hline Online shopping & 1 & 0.27 \\
\hline Playing games & 17 & 4.67 \\
\hline Browsing & 1 & 0.27 \\
\hline Digital drawing & 1 & 0.27 \\
\hline Fun & 1 & 0.27 \\
\hline Online lectures & 16 & 4.40 \\
\hline Reading ebooks (books, novels, and comics) & 7 & 1.92 \\
\hline Listening to music & 1 & 0.27 \\
\hline Doing online assignments & 1 & 0.27 \\
\hline Watching videos & 71 & 19.51 \\
\hline Online meetings & 2 & 0.55 \\
\hline Social media & 245 & 67.31 \\
\hline \multicolumn{3}{|l|}{ Sleeping time } \\
\hline$<23.00$ & 70 & 19.23 \\
\hline $23.00-00.00$ & 196 & 53.85 \\
\hline$>00.00$ & 98 & 26.92 \\
\hline \multicolumn{3}{|l|}{ Sleep duration } \\
\hline$<7 \mathrm{~h}$ & 143 & 39.29 \\
\hline $7-9 \mathrm{~h}$ & 216 & 59.34 \\
\hline$>9 \mathrm{~h}$ & 5 & 1.37 \\
\hline
\end{tabular}

In terms of the duration of smartphone use per day, major respondents used the device for $4-8 \mathrm{~h}$ ( $n=207 ; 56.87 \%$ ). In addition, we also found that there were three main purposes of the smartphone use by respondents: to access social media ( $n=245$; $67.31 \%)$, watch videos ( $\mathrm{n}=71 ; 19.51 \%)$, and play games ( $\mathrm{n} w=17 ; 4.67 \%)$. This study also found out that most respondents had a bedtime of $23.00-00.00$ $(n=196 ; 53.85 \%)$. On the other hand, major respondents had a sleep duration of $7-9 h(n=216 ; 59.34 \%)$.

Based on the results of the Smartphone Addiction Scale-Short Version (SAS-SV) questionnaire analysis, it was found that the majority of respondents experienced high addiction ( $n=212 ; 58.24 \%$ ) while other students experienced low addiction ( $n=152 ; 41.76 \%$ ). The description of smartphone addiction is presented in Table 2.

\section{Table 2: Overview of smartphone addiction}

\begin{tabular}{lll}
\hline Smartphone addiction category & Frequency $(\mathrm{n})$ & Percentage \\
\hline Low addiction & 152 & 41.76 \\
High addiction & 212 & 58.24 \\
\hline
\end{tabular}

Based on the results of the Insomnia Severity Index (ISI) questionnaire analysis, it was found that the majority of respondents experienced mild insomnia $(n=187 ; 51.37 \%)$. Moderate insomnia $(n=87 ; 23.90 \%)$ and severe insomnia $(n=13 ; 3.57 \%$ ) were experienced by some respondents. An overview of the incidence of insomnia is presented in Table 3.

Table 3: Overview of the incidence of insomnia

\begin{tabular}{lll}
\hline Insomnia Category & Frequency $(\mathrm{n})$ & Percentage \\
\hline No clinically significant insomnia & 77 & 21.15 \\
Subthreshold insomnia & 187 & 51.37 \\
Moderate clinical insomnia & 87 & 23.90 \\
Severe clinical insomnia & 13 & 3.57 \\
\hline
\end{tabular}

Based on the results of data analysis, it was found that smartphone addiction as an independent variable had a significant relationship $(p=0.002)$ with weak and positive correlation $(r=0.162)$ to the incidence of insomnia as the dependent variable. Each category of variables, both smartphone addiction and insomnia, fulfills every column and row of the analysis table. The relationship between them is presented in Table 4 .

Table 4: The association between smartphone addiction and insomnia incidence

\begin{tabular}{|c|c|c|c|c|c|c|}
\hline \multirow[t]{3}{*}{ Smartphone addiction } & \multicolumn{4}{|c|}{ Insomnia } & \multirow[t]{3}{*}{$r$} & \multirow[t]{3}{*}{$p$} \\
\hline & \multicolumn{2}{|l|}{ No } & \multicolumn{2}{|l|}{ Yes } & & \\
\hline & $n$ & $\%$ & $\mathrm{n}$ & $\%$ & & \\
\hline Low & 44 & 28.9 & 108 & 71.1 & 0.162 & 0.002 \\
\hline High & 33 & 15.6 & 179 & 84.4 & & \\
\hline
\end{tabular}

\section{Discussion}

The rapid improvement of information and communication technology is directly equivalent to the increase of smartphone users, especially among teenagers. The high level of intensity of device using can cause side effects for users. Various studies have succeeded in finding the side effects of addiction due to excessive use of smartphones among teenager respondents [18], [19], [20], [21], [22], [23], [24], [25]. The condition of smartphone addiction can contribute to the development of various pathological conditions. This research aims to determine the association between smartphone addiction and one type of pathological condition that can arise, namely, insomnia.

Based on the research that has been done, several socio-demographic characteristics can be analyzed for association with smartphone addiction 
and insomnia. Data on the socio-demographic characteristics of the research subjects in terms of age showed that most of the respondents were 19 years old. This phenomenon occurs because the respondents who are the research subjects come from $1^{\text {st }}$-year medical students. Similar age characteristics were also received in Ramadhani's research regarding the relationship between smartphone addiction and insomnia [26]. The research was conducted in North Sumatra with medical students as respondents and discovered that the average age of the respondents was 19.71 years. Similarities in terms of the characteristics of the respondent's age variable can also be found in other studies, but these studies do not specifically mention the trend of respondent's age [16], [23], [27]. Research by Akbulut Zencirci et al. obtained most (53\%) of respondents who are in the range of 18-20 years. Ibrahim et al. who examined the relationship between smartphone addiction and sleep quality in medical students at King Abdulaziz University found that most of the research respondents were $<22$ years old (<22 years). Recently, research managed by Sohn et al. found that the characteristics of the respondent's age were dominated by age $\leq 21$ years ( $\leq 21$ years).

In terms of gender characteristics, most of the respondents in this research are female. This happened because the prevalence of female students is higher than male students. Comparable gender characteristics of respondents were also found by several types of research regarding the association between smartphone addiction and insomnia [14], [16], [23], [26], [27], [28], [29]. The percentage difference between female and male respondents in these studies varied in the range of $2-53 \%$. Analysis of the association between gender differences and the prevalence of smartphone addiction and insomnia was not carried out in these studies. However, several previous studies found that there was no significant difference in terms of gender in the percentage of smartphone addiction cases prevalence [14], [21]. Different research results were obtained by Demirci et al. who discovered that the prevalence of smartphone addiction tends to be higher in the female gender group [29]. The research stated that the high level of addiction in females was caused by the use of the communication function and access to social networks from smartphones to socialize intensely [29]. The association between gender differences and the prevalence of insomnia has been examined by Suh et al. through a review published in 2018 [30]. Women have a risk of developing insomnia 1.5 times higher than men. The existence of socioeconomic factors, physiological factors (hormones), and psychological factors (personality) is the three main things that can contribute to gender differences in the prevalence of insomnia [30].

In grouping research results based on the characteristics of the respondents' study programs, it was found that most of the respondents came from the medical study program. This result is supported by the evidence that the quantity of $1^{\text {st }}$-year students of the Faculty of Medicine, Universitas Udayana is dominated by students of the Medicine study program. Research by Sohn et al. in the UK also has the same characteristics of the respondent's study program, which is dominated by medical students, specifically $36.7 \%$ of the total sample [27]. Based on the SAS-SV scores obtained by the respondents, our research found that most of the samples experienced smartphone addiction. The assessment of the respondent's insomnia level using the ISI indicates that the prevalence of insomnia cases among the $1^{\text {st }}$-year medical students was quite high. This research also found that there was an association between smartphone addiction with high addiction rates and insomnia. Various studies on smartphone addiction, insomnia, and their association were conducted on medical students and discovered the same results [14], [16], [22], [31], [32], [33]. The high number of smartphone addictions in medical students can be caused by the length of time spent using these devices, whether they are used as learning tools, attending lectures, or getting entertainment [22], [34]. On the other hand, the development of insomnia conditions in medical students is influenced by multiple factors, such as learning styles, educational curriculum, and student study degree [33].

Our research also found that the average duration of smartphone use of the respondents was 4-8 h/day. Similar results were also obtained by Alhazmi et al. and Al-Shahrani et al. The results of these two studies indicate that the duration of the respondent's smartphone use is more than equal to $4 \mathrm{~h}(\geq 4 \mathrm{~h})$ [22], [34]. Different research results were obtained by Haug et al. and Lukman [20], [35]. Research by Haug et al. conducted in Switzerland found a characteristic trend of respondents' smartphone usage duration is 3-4 h/day [20]. Meanwhile, most of the respondents' smartphone usage duration characteristics in the research by Lukman reached more than $6 \mathrm{~h}$ (>6 h) per day [35]. Smartphone use for more than $5 \mathrm{~h}$ is categorized as excessive device use and has the potential to cause pathological conditions such as insomnia and depression [36], [37].

Through the data from our research, the types of smartphone use by respondents are quite varied but dominated by use for reaching social media. The frequency and duration of excessive social media access can result in the development of social media addiction conditions. This type of addiction has a positive association with the development of smartphone addiction. The association arises because access to social media requires a communication and information device that is connected by an internet network such as a smartphone. Similarities in the characteristics of the type of smartphone use were also obtained in various studies that had been conducted previously [20], [23], [31], [34], [38]. All the results of these 
studies indicate that the characteristics of smartphone use are related to the interests of gaining access to social media. In addition, research by Abdalqader et al. in Malaysia succeeded to find a positive association between the duration and frequency of social media use with the prevalence of insomnia cases in university students $(p=0.005)$ [39].

In general, the respondents who became the sample of our research had sleep time in the range of 23.00-00.00 (GMT+8). Similar characteristics of the respondent's sleep time were also obtained in the research in Japan. Research held by Tamura et al. indicates that the respondents, namely, teenagers, tend to sleep in the range of 23.00-00.00 (GMT+9) [37]. The characteristics of sleep during this period can interfere adolescent growth and development process. Based on the physiological clock of a person's body, 23.00-02.00 is the period for the pituitary gland to produce a hormone called Human Growth Hormone (HGH). Inhibited sleep time and the existence of sleep disturbances can affect the development and growth process in adolescents because $\mathrm{HGH}$ secretion occurs in the first phase of slow-wave sleep [40].

The American Academy of Sleep Medicine recommends adolescents get enough sleep with a duration of $8-10 \mathrm{~h}$ because adolescents will experience the second period of growth and cognitive development [41]. Sleep duration is the total time spent when a person begins to fall asleep until he wakes up again. The results of our research showed that most of the respondents still had normal sleep duration with the total time spent sleeping within 7-9 h. The results of research in Hong Kong that assessed the association between smartphone screen viewing time and sleep quality found that the average sleep duration for adolescents was $7.74 \mathrm{~h}$ [36]. However, our research also found that there were students with less sleep duration. ( $<7 \mathrm{~h}$ ) with a fairly high prevalence. As students, respondents have demands or obligations to complete assignments or study. Both of these things will indirectly affect the use of smartphones with high intensity. Excessive use of smartphones has an impact on disrupting the quality and duration of a person's sleep, which can lead to insomnia.

Based on the smartphone addiction assessment results using SAS-SV, it was found that the majority of respondents experienced high levels of smartphone addiction. Various factors linked to the prevalence of smartphone addiction are social, psychological, technological, and family factors. Some of the factors that we have found are consistent with other studies which state that smartphone addiction is caused by certain factors such as the duration of smartphone use, smartphone ownership, use of social sites, and the absence of restrictions on smartphone use [42]. However, the biggest factor that plays an important role in the level of addiction to smartphones is the COVID-19 pandemic situation.
During the pandemic era, rules about social distancing are strictly enforced to prevent the spread of the COVID-19 virus [43]. Hence, human social needs in the pandemic era are obtained in other ways, one of which is the use of smartphones to access social media [44]. According to numerous existing studies, this incident had a major impact on the increasing intensity and duration of smartphone use during the pandemic era [45], [46].

Aside from limiting social interactions, the pandemic also has an impact on developing mental disorders such as depression and anxiety. In a meta-analysis by Bueno-Notivol et al., it was discovered that during the COVID-19 pandemic, the prevalence of depression increased by 7 times [47]. The enhancement in the incidence of depression and anxiety is also a risk factor in the development of smartphone addiction condition [8], [9], [17]. Psychopathological problems will increase the frequency of smartphone use which is used as a form of coping mechanism from problems encountered in real life [7]. Smartphones are used as an entertainment tool, such as watching videos, playing games, listening to music, and others.

Technological factors also contribute to the severity of smartphone addiction. Smartphones have encountered significant developments in terms of innovation and features during the pandemic era. Innovations, such as telehealth, virtual care, and other forms of technology [48], [49], are the main attraction of smartphones. In addition, the features on the smartphone also support the respondent's activities such as online meetings, work on assignments, and various other things. Elaborating innovations and features of smartphones will indirectly increase the demand for smartphones in the pandemic era [46].

In addition to those three factors, family is also the main contributing factor leading to smartphone addiction. The family holds an important role in the pattern of respondent's smartphones use [50]. If the family has certain rules regarding the use of smartphones, it will affect the habits of smartphone users. Some research implicates that there was a significant association between smartphone use and family relationships [51], [52]. This is an important point which states that smartphone addiction can be influenced by family factors.

Based on the results of the ISI questionnaire analysis, it was found that the majority of respondents experienced mild insomnia. This is because the respondents are in the early stages of insomnia disorder. In addition, insomnia experienced by the majority of respondents did not significantly interfere with the respondent's quality of life. There are several related factors in this study, for example, the duration of the learning, the use of smartphones, and the presence of mental disorders such as depression and anxiety, as well as environmental factors. 
Several studies related to insomnia among university students have previously been carried out, in Malaysia obtained 69\% experiencing insomnia [39]. Then in Ethiopia, about $61.6 \%$ of college students experienced insomnia [53]. Research in Pakistan shows $40.74 \%$ of medical students experience insomnia [33]. Then in Nepal, about $90 \%$ of college students experience insomnia [54]. In contrast to other studies, research in Lebanon showed a lower rate of $10.6 \%$ of students experiencing insomnia [55]. Another similar study in Saudi Arabia showed a figure of $19.3 \%$ [56].

Based on the results of dataanalysis, itwas found that smartphone addiction had a significant relationship with the incidence of insomnia. Smartphone addiction is often characterized by excessive smartphone use, both in terms of frequency and duration. In addition, people who experience smartphone addiction find it difficult to control themselves not to use their smartphones [57]. Uncontrolled use of smartphones will consume users time in a day, so the portion of time for other activities will be spent playing smartphones [58]. As a result of this, one of the reduced times due to smartphone use is sleep. Reduced sleep time, affects the quantity and quality of sleep [58]. Low quality and quantity of sleep will cause insomnia. This can be evidence that smartphone addiction is a risk factor for insomnia [37]. Similar studies have been conducted and state the same thing that smartphone addiction has a relationship with the incidence of sleep disorders (insomnia) both in terms of quality and quantity [15], [16], [17], [29], [59], [60], [61], [62], [63], [64], [65].

\section{Conclusion}

Based on the results of data analysis, it was found that the majority of respondents experienced high levels of smartphone addiction and mild insomnia. Smartphone addiction is known to have a significant relationship with weak and positive correlation to the incidence of insomnia in respondents. This finding suggests the higher addiction to the smartphones, the more severe insomnia suffered. Education needs to be given regarding the impact of smartphone use addiction and insomnia.

\section{References}

1. World Health Organization. WHO Director-General's Opening Remarks at the Media Briefing on COVID-19 Internet. Geneva: World Health Organization; 2020.

2. Ristyawati A. The effectiveness of large scale social restriction policy from government as stated on UUD NKRI Year 1945 during corona virus 2019 pandemic. Adm Law Gov J. 2020;3(2):240-9. https://doi.org/10.14710/alj.v3i2.240-249

3. Azzahra NF. Indonesia during covid-19 pandemic crisis era Summary of the policy. Ringkasan Kebijak. 2020;19(2):1-9.

4. Sari W, Rifki AM, Karmila M. Distance learning in the covid-19 era. J Mappesona. 2020;(1):12. https://doi.org/10.18860/mad. v13i2.11330

5. Maknuni J, Artikel I. Indonesian education pengaruh media belajar smartphone terhadap belajar siswa di era pandemi Covid-19 (The influence of smartphone learning media on student learning in the era pandemi Covid-19). Indones Educ Adm Leadersh J. 2020;2:94-106.

6. Ramadhani IR, Fathurohman I, Fardani MA. Efek Penggunaan Smartphone berkelanjutan pada Masa Pandemi Covid-19 terhadap Perilaku Anak. J Amal Pendidik. 2020;1(2):10. http:// dx.doi.org/10.36709/japend.v1i2.13293

7. Panova $T$, Carbonell $X$. Is smartphone addiction really an addiction? J Behav Addict. 2018;7(2):252-9. http://dx.doi. org/10.1556/2006.7.2018.49

PMid:29895183

8. Boumosleh JM, Jaalouk D. Depression, anxiety, and smartphone addiction in university students a cross sectional study. PLoS One. 2017;12(8):e0182239. http://dx.doi.org/10.1371/journal. pone. 0182239

PMid:28777828

9. Alhassan AA, Alqadhib EM, Taha NW, Alahmari RA, Salam M, Almutairi AF. The relationship between addiction to smartphone usage and depression among adults: A cross sectional study. BMC Psychiatry. 2018;18(1):148. https://doi.org/10.1186/ s12888-018-1745-4

10. Rini MK, Huriah T. The prevalence and impact of smartphone addiction in adolescent: Literature review. J Keperawatan Muhammadiyah. 2020;5(1):185-94. http://dx.doi.org/10.30651/ jkm.v5i1.4609

11. Patel D, Steinberg J, Patel P. Insomnia in the elderly: A review. J Clin Sleep Med. 2018;14(6):1017-24. http://dx.doi.org/10.5664/ jcsm.7172

PMid:29852897

12. Voitsidis P, Gliatas I, Bairachtari V, Papadopoulou K, Papageorgiou G, Parlapani E, et al. Insomnia during the COVID-19 pandemic in a Greek population. Psychiatry Res. 2020;289:113076. http://dx.doi.org/10.1016/j. psychres.2020.113076

PMid:32434093

13. Kokou-Kpolou CK, Megalakaki O, Laimou D, Kousouri M. Insomnia during COVID-19 pandemic and lockdown: Prevalence, severity, and associated risk factors in French population. Psychiatry Res. 2020;290:113128. http://dx.doi. org/10.1016/j.psychres.2020.113128 PMid:32563951

14. Kumar VA, Vigneshvar C, Brahadeeswari $H$. Prevalence of smartphone addiction and its effects on sleep quality: A crosssectional study among medical student. Ind Psychiatry J. 2019;28(1):82-5. http://dx.doi.org/10.4103/ipj.ipj_56_19 PMid:31879452

15. Al Battashi N, Al Omari O, Sawalha M, Al Maktoumi S, Alsuleitini A, Al Qadire M. The relationship between smartphone use, insomnia, stress, and anxiety among university students: A cross-sectional study. Clin Nurs Res. 2021;30(6):734-40. http://dx.doi.org/10.1177/1054773820983161 PMid:33375850

16. Ibrahim NK, Baharoon BS, Banjar WF, Jar AA, Ashor RM, Aman AA, et al. Mobile phone addiction and its relationship to sleep quality and academic achievement of medical students at King Abdulaziz University, Jeddah, Saudi Arabia. J Res Health 
Sci. 2018;18(3):e00420.

PMid:30270211

17. Bhatt S, Gaur A. Psychological risk factors associated with internet and smartphone addiction among students of an Indian dental institute. Indian J Public Health. 2019;63(4):313-7. http:// dx.doi.org/10.4103/ijph.IJPH_330_18

PMid:32189650

18. Mazaheri MA, Karbasi M. The use of mobile phone features among students in isfahan university of medical sciences in Iran. Scimetr. 2014;2(3):101-5. http://dx.doi.org/10.5812/ scimetr. 18760

19. Lopez-Fernandez O, Honrubia-Serrano L, Freixa-Blanxart M, Gibson W. Prevalence of problematic mobile phone use in british adolescents. Cyberpsychol Behav Soc Netw. 2014;17(2):91-8. http://dx.doi.org/10.1089/cyber.2012.0260

PMid:23981147

20. Haug S, Castro RP, Kwon M, Filler A, Kowatsch T, Schaub MP. Smartphone use and smartphone addiction among young people in Switzerland. J Behav Addict. 2015;4(4):299-307. http://dx.doi.org/10.1556/2006.4.2015.037

PMid:26690625

21. Chen B, Liu F, Ding S, Ying X, Wang L, Wen Y. Gender differences in factors associated with smartphone addiction: A cross-sectional study among medical college students. BMC Psychiatry. 2017;17(1):341. http://dx.doi.org/10.1186/ s12888-017-1503-z

PMid:29017482

22. Alhazmi AA, Alzahrani SH, Baig M, Salawati EM, Alkatheri A. Prevalence and factors associated with smartphone addiction among medical students at King Abdulaziz University, Jeddah. Pakistan J Med Sci. 2018;34(4):984-8.

PMid:30190766

23. Zencirci SA, Aygar H, Göktaş S, Önsüz MF, Alaiye M, Metintaş S Evaluation of smartphone addiction and related factors among university students. Int J Res Med Sci. 2018;6(7):2210. http:// dx.doi.org/10.18203/2320-6012.ijrms20182805

24. Tateno M, Teo AR, Ukai W, Kanazawa J, Katsuki R, Kubo H, et al. Internet addiction, smartphone addiction, and hikikomori trait in Japanese young adult: Social isolation and social network. Front Psychiatry. 2019;10:455. http://dx.doi.org/10.3389/ fpsyt.2019.00455

PMid:31354537

25. Buctot DB, Kim N, Park KE. Development and evaluation of smartphone detox program for university students. Int J Contents. 2018;14(4):1-9. https://doi.org/10.1016/j.ssaho.2020.100035

26. Ramadhani S. Hubungan Lama Penggunaan Gadget Dengan Kejadian Insomnia Pada Mahasiswa Fakultas Kedokteran Universitas Sumatera Utara. Medan, Indonesia: Repository University of Sumatera Utara. 2021.

27. Sohn SY, Krasnoff L, Rees P, Kalk NJ, Carter B. The association between smartphone addiction and sleep: A UK cross-sectional study of young adults. Front Psychiatry. 2021;12:629407. https://doi.org/10.3389/fpsyt.2021.629407

28. Sahin S, Ozdemir K, Unsal A, Temiz N. Evaluation of mobile phone addiction level and sleep quality in university students. Pakistan J Med Sci. 2013;29(4):913-8. https://doi.org/10.12669/ pjms.294.3686

PMid:24353658

29. Demirci K, Akgönül M, Akpinar A. Relationship of smartphone use severity with sleep quality, depression, and anxiety in university students. J Behav Addict. 2015;4(2):85-92. PMid:26132913

30. Suh S, Cho N, Zhang J. Sex differences in insomnia: From epidemiology and etiology to intervention. Curr Psychiatry
Rep. 2018;20(9):69. https://doi.org/10.1007/s11920-018-0940-9 PMid:30094679

31. Kurugodiyavar MD, Sushma HR, Godbole M, Nekar MS. Impact of smartphone use on quality of sleep among medical students. Int J Community Med Public Health. 2017;5(1):101. http://dx.doi. org/10.18203/2394-6040.ijcmph20175604

32. Gowda GS, Komal S, Sanjay TN, Mishra S, Kumar CN, Math SB Sociodemographic, legal, and clinical profiles of female forensic inpatients in Karnataka: A retrospective study. Indian J Psychol Med. 2019;41(2):138-43. http://dx.doi.org/10.4103/IJPSYM. IJPSYM_152_18

PMid:30983661

33. Shakeel HA, Maqsood H, Ishaq A, Ali B, Hussain H, Khan AR, et al. Insomnia among medical students: A cross-sectional study. Int J Res Med Sci. 2019;7(3):893. http://dx.doi. org/10.18203/2320-6012.ijrms20190944

34. Al-Shahrani M. Smartphone addiction among medical students in Bisha, Saudi Arabia. J Fam Med Prim Care. 2020;9(12):591620. http://dx.doi.org/10.4103/jfmpc.jfmpc_1205_20 PMid:33681019

35. Lukman. Penggunaan dan Adiksi Smartphone di Kalangan Mahasiswa Fakultas Kedokteran Universitas Hasanuddin Angkatan 2015 Dan 2016. Indonesia: Hasanuddin University; 2018.

36. Mak YW, Wu CS, Hui DW, Lam SP, Tse HY, Yu WY, et al. Association between screen viewing duration and sleep duration, sleep quality, and excessive daytime sleepiness among adolescents in Hong Kong. Int J Environ Res Public Health. 2014;11(11):11201-19. http://dx.doi.org/10.3390/ ijerph111111201

PMid:25353062

37. Tamura H, Nishida T, Tsuji A, Sakakibara H. Association between excessive use of mobile phone and insomnia and depression among Japanese adolescents. Int J Environ Res Public Health. 2017;14(7):701. http://dx.doi.org/10.3390/ijerph14070701 PMid:28661428

38. Kaya F, Daştan NB, Durar E. Smart phone usage, sleep quality and depression in university students. Int J Soc Psychiatry. 2021;67(5):407-14. http://dx.doi. org/10.1177/0020764020960207 PMid:32969293

39. Abdalqader MA, Ariffin IA, Ghazi HF, AboBakr MF, Fadzil MA Prevalence of insomnia and its association with social media usage among university students in Selangor, Malaysia, 2018. Folia Med Indones. 2018;54(4):289-93. http://dx.doi. org/10.20473/fmi.v54i4.10715

40. Van Cauter E, Copinschi G. Interrelationships between growth hormone and sleep. Growth Horm IGF Res. 2000;10(Suppl $\quad$ B):S57-62. http://dx.doi.org/10.1016/ s1096-6374(00)80011-8

PMid:10984255

41. Paruthi S, Brooks LJ, D'Ambrosio C, Hall WA, Kotagal S Lloyd RM, et al. Consensus statement of the american academy of sleep medicine on the recommended amount of sleep for healthy children: Methodology and discussion. J Clin Sleep Med. 2016;12(11):1549-61.

PMid:27707447

42. Buctot DB, Kim N, Kim JJ. Factors associated with smartphone addiction prevalence and its predictive capacity for health- related quality of life among Filipino adolescents. Child Youth Serv Rev. 2020;110:104758. http://dx.doi.org/10.1016/j. childyouth.2020.104758

43. Williams N. Social distancing in the Covid-19 pandemic. Occup Med (Chic III). 2020;70(5):305.

44. David ME, Roberts JA. Smartphone use during the COVID- 19 
pandemic: Social versus physical distancing. Int $\mathrm{J}$ Environ Res Public Health. 2021;18(3):1034. http://dx.doi.org/10.3390/ ijerph18031034

PMid:33503907

45. Li T, Zhang M, Li Y, Lagerspetz E, Tarkoma S, Hui P. The impact of Covid-19 on smartphone usage. IEEE Internet Things $\mathrm{J}$. 2021;1:99. http://dx.doi.org/10.1109/JIOT.2021.3073864

46. MMA. Covid19 Effects on Mobile and Digital Media Mobile Time in Italy and China Increased. MMA; 2020. p. 1-14.

47. Bueno-Notivol J, Gracia-García P, Olaya B, Lasheras I, LópezAntón R, Santabárbara J. Prevalence of depression during the COVID-19 outbreak: A meta-analysis of community-based studies. Int J Clin Heal Psychol. 2021;21(1):100196. http:// dx.doi.org/10.1016/j.ijchp.2020.07.007 PMid:32904715

48. Clipper B. The influence of the COVID-19 Pandemic on Technology: Adoption in Health Care. Nurse Lead. 2020;18(5):500-3. http://dx.doi.org/10.1016/j.mnl.2020.06.008 PMid:32837346

49. Mbunge E, Akinnuwesi B, Fashoto SG, Metfula AS, Mashwama P. A critical review of emerging technologies for tackling COVID-19 pandemic. Hum Behav Emerg Technol. 2021;3(1):25-39. https://doi.org/10.1002/hbe2.237

50. Sophie H, Ortner C, Sophie H. Ortner Christina on the Role of Smartphones for Family Relationships. Children and Adolescents in a Mobile Media World. Pre-Conference to ECREA's; 2018.

51. Ccama YP. Use of smartphones in family relationships of university students of the Nacional del Altiplano University of Puno. Comun Rev Investig. 2019;10(2):151-9. https://doi. org/10.33595/2226-1478.10.2.387

52. Nurhayati P, Nugraha PD, Devi HP, Utomo AW. Impact analysis of smartphone use and youth family development (BKR) program on family disharmony in Magetan Regency. Simulacra J Sosiol. 2020;3(1):95-107. https://doi.org/10.21107/sml.v3i1.7038

53. Haile YG, Alemu SM, Habtewold TD. Insomnia and its temporal association with academic performance among university students: A cross-sectional study. Biomed Res Int. 2017;2017:2542367. https://doi.org/10.1155/2017/2542367 PMid:28752093

54. Magar S, Mali P, Baskota S, Pandey KR. Insomnia and its associated factor among young adults in selected college of kathmandu valley province-3. Nepal Med J. 2019;2(2):28-32. https://doi.org/10.37080/nmj.66

55. Choueiry N, Salamoun T, Jabbour H, El Osta N, Hajj A, Khabbaz LR. Insomnia and relationship with anxiety in university students: A cross-sectional designed study. PLoS
One. 2016;11(2):e0149643.

PMid:26900686

56. Albasheer OB, Al Bahhawi T, Ryani MA, Arishi AM, Hakami OM Maashi SM, et al. Prevalence of insomnia and relationship with depression, anxiety and stress among Jazan university students: A cross-sectional study. Cogent Psychol. 2020;7(1):1789424. https://doi.org/10.1080/23311908.2020.1789424

57. Ting $\mathrm{CH}$, Chen YY. Adolescent addiction. In: Smartphone Addiction. $2^{\text {nd }}$ ed. Amsterdam, Netherlands: Elsevier Inc.; 2020. p. 215-40.

58. Mehrnaz M, Farahnaz M, Gholamreza K, Mohseni KH, Homayoon SS, Majid N. Smartphone addiction, sleep quality and mechanism. Int J Cogn Behav. 2018;1(1):2. https://doi. org/10.23937/IJCB-2017/1710002

59. De Pasquale $C$, Sciacca F, Hichy $Z$. Italian validation of smartphone addiction scale short version for adolescents and young adults (SAS-SV). Psychology. 2017;8(10):1513-8. https:// doi.org/10.4236/psych.2017.810100

60. Akın A, Altundağ $Y$, Turan ME, Akın U. The validity and reliability of the turkish version of the smart phone addiction scale-short form for adolescent. Proc Soc Behav Sci. 2014;152:74-7. https://doi.org/10.1371/journal.pone.0083558

61. Pelayo R, Yuen K. Pediatric sleep pharmacology. Child Adolesc Psychiatr Clin North Am. 2012;21(4):861-83. https://doi. org/10.1016/j.chc.2012.08.001 PMid:23040905

62. Bruni O, Alonso-Alconada D, Besag F, Biran V, Braam W, Cortese $\mathrm{S}$, et al. Current role of melatonin in pediatric neurology: Clinical recommendations. Eur J Paediatr Neurol. 2015;19(2):122-33. https://doi.org/10.1016/j.ejpn.2014.12.007 PMid:25553845

63. Clarke G, McGlinchey EL, Hein K, Gullion CM, Dickerson JF, Leo MC, et al. Cognitive-behavioral treatment of insomnia and depression in adolescents: A pilot randomized trial. Behav Res Ther. 2015;69:111-8. https://doi.org/10.1016/j.brat.2015.04.009 PMid:25917009

64. Ayar D, Bektas M, Bektas I, Kudubes AA, Ok YS, Altan SS, et al. The effect of adolescents' internet addiction on smartphone addiction. J Addict Nurs. 2017;28(4):210-4. https://doi. org/10.1097/JAN.0000000000000196 PMid:29200048

65. Cheung LM, Wong WS. The effects of insomnia and internet addiction on depression in Hong Kong Chinese adolescents: An exploratory cross-sectional analysis. J Sleep Res. 2011;20(2):311-7. http://doi. org/10.1111/j.1365-2869.2010.00883.x

PMid:20819144 